\title{
Addition of calcium compounds to reduce soluble oxalate in a high oxalate food system
}

\author{
Wen-Chun Bong, Leo P. Vanhanen, Geoffrey P. Savage* \\ Food Group, Department of Food, Wine and Molecular Biosciences, Faculty of Agriculture and Life Sciences, Lincoln University, Canterbury, New Zealand
}

\section{A R T I C L E I N F O}

\section{Article history:}

Received 30 July 2016

Received in revised form 5 October 2016

Accepted 7 October 2016

Available online 8 October 2016

\section{Keywords:}

Spinach

Soluble oxalate

Calcium salts

$\mathrm{pH}$

\begin{abstract}
A B S T R A C T
Spinach (Spinacia oleracea L.) is often used as a base vegetable to make green juices that are promoted as healthy dietary alternatives. Spinach is known to contain significant amounts of oxalates, which are toxic and, if consumed regularly, can lead to the development of kidney stones. This research investigates adding 50-500 mg increments of calcium carbonate, calcium chloride, calcium citrate and calcium sulphate to $100 \mathrm{~g}$ of raw homogenates of spinach to determine whether calcium would combine with the soluble oxalate present in the spinach. Calcium chloride was the most effective additive while calcium carbonate was the least effective. The formation of insoluble oxalate after incubation at $25^{\circ} \mathrm{C}$ for $30 \mathrm{~min}$ is a simple practical step that can be incorporated into the juicing process. This would make the juice considerably safer to consume on a regular basis.
\end{abstract}

(c) 2016 Elsevier Ltd. All rights reserved.

\section{Introduction}

Juicing fruit and vegetables is widely promoted on the internet. It is frequently claimed that during the juicing process the nutrients from fruit and vegetables will become more available and, therefore, be absorbed more easily from the digestive system. Nutritionists and dietitians universally encourage increased consumption of fruit and vegetables in the diet but no scientific evidence is available to suggest that juicing has any extra advantages. Juicing or "juice cleansing" was first claimed to meet the body's requirements for enzymes for optimal health by Walker (1951). More recently, spinach has been recognised to contain high levels of vitamins, minerals and phytochemicals (Liu et al., 2015) and these are now being widely promoted.

The potential negative effects of consuming large amounts of vegetable juices are rarely discussed. Excess consumption of juices can lead to weight gains due to excessive energy intakes (Wang, Bleich, \& Gortmaker, 2008). Getting, Gregoire, Phul, and Kasten (2013) reported a case of acute renal failure in an adult male following six weeks' consumption of a mixed fruit and vegetable juice diet. The mixed juice contained significant amounts of spinach, which contains high levels of oxalates. Excessive consumption of star fruit juice, which also contains high levels of oxalates, have been shown to lead to acute renal injury (Fang et al., 2008). The moderate or occasional consumption of juices that may contain

\footnotetext{
* Corresponding author.

E-mail address: Savage@lincoln.ac.nz (G.P. Savage).
}

some toxins, such as oxalates, is unlikely to cause problems. It is the consumption of a diet consisting only of juice for long periods of time that is of concern.

Spinach is a popular green leafy vegetable and is commonly added to homemade fruit and vegetable juices due to its low cost, availability, and the fact that it is easy to grow in home gardens. The high oxalate content of spinach is well documented in foodrelated scientific literature (Massey 2003; Noonan \& Savage, 1999; Savage, Vanhanen, Mason, \& Ross, 2000) but general public awareness is sometimes limited. Recently, reported levels of total, soluble and insoluble oxalates were in the ranges of: 329.6-1764.7, 266.5-736.6 and 40.2-1400.1 mg/100 g fresh weight (FW) (Akhtar, Israr, Bhatty, \& Ali, 2011; Brogren \& Savage, 2003; Ghosh Das \& Savage, 2013; Noonan \& Savage, 1999; Savage, Martensson, \& Sedcole, 2009; Savage et al., 2000). Soluble oxalates in plant foods are found bound to $\mathrm{Na}^{+}, \mathrm{K}^{+}$and $\mathrm{NH}^{4+}$ and insoluble oxalates are commonly bound to $\mathrm{Ca}^{2+}, \mathrm{Mg}^{2+}$ and $\mathrm{Fe}^{2+}$ (Savage et al., 2000). During food processing, cooking and during passage through the digestive tract soluble oxalates can become bound to $\mathrm{Ca}^{2+}, \mathrm{Mg}^{2+}$ and $\mathrm{Fe}^{2+}$ to form insoluble oxalates. Insoluble oxalates are less likely to be absorbed in the digestive tract (Liebman \& Costa, 2000; Massey, 2003; Noonan \& Savage, 1999).

A recent study has shown that a green juice recipe widely promoted on the internet, and containing a mixture of apple, celery, cucumber, green pepper, red capsicum, lemon and parsley, along with either $300 \mathrm{~g}$ or $600 \mathrm{~g}$ of spinach, could have soluble oxalate levels ranging from 78 to $364.09 \mathrm{mg} / 100 \mathrm{~g}$ FW (Vanhanen \& Savage, 2015). Regular consumption of high oxalate juices may 
increase the risk of kidney damage in susceptible individuals due to oxalate stone formation (Massey, 2003; Noonan \& Savage, 1999). Consumption of a $200 \mathrm{~mL}$ glass of a typical juicing recipe containing spinach would deliver $728.2 \mathrm{mg}$ of soluble oxalates, a significant amount, while the consumption of six glasses/day would deliver $4369.2 \mathrm{mg}$ of soluble oxalates. This is a considerable excess when compared with the estimated daily intake of total oxalate for omnivores, which ranges from 70 to $930 \mathrm{mg}$ and, for vegetarians, which ranges from 80 to $2000 \mathrm{mg}$ (Ogawa, Miyazato, \& Hatano, 2000).

The risk posed by soluble oxalates (Getting et al., 2013: Vanhanen \& Savage, 2015) has driven studies to identify methods to reduce the absorption of soluble oxalates in foods. Avoiding foods that are known to contain high levels of oxalates and increasing fluid intake will reduce oxalate intake and subsequent output in the urine (Massey, 2003; Noonan \& Savage, 1999). Certain processing methods, such as cooking and soaking, can lead to the loss of soluble oxalate into the cooking water (Savage et al., 2000) and this will reduce the oxalate available for absorption from the digestive tract. Oxalic acid forms water-soluble salts when it binds to $\mathrm{Na}^{+}, \mathrm{K}^{+}$and $\mathrm{NH}^{4+}$ ions, and insoluble oxalates when it binds to $\mathrm{Ca}^{2+}, \mathrm{Fe}^{2+}$ and $\mathrm{Mg}^{2+}$ ions (Noonan \& Savage, 1999). Another strategy to decrease the absorption of soluble oxalate from food is to encourage it to form insoluble oxalates. Studies have found that soluble oxalate levels decreased when foods with high levels of calcium were consumed along with foods containing high levels of soluble oxalates. The addition of calcium from milk during the cooking process, or calcium salts during manufacturing, was also able to convert the soluble oxalates into insoluble oxalates (Brogren \& Savage 2003; Faudon \& Savage 2014; Oscarsson \& Savage, 2007; Savage, Charrier, \& Vanhanen, 2003; Simpson, Savage, Sherlock, \& Vanhanen, 2009).

Calcium salts are widely accepted and used as acidity regulators, firming agents and stabilisers in processed foods (Msagati, 2012; Saltmarsh, 2013; Wang, 2012). The addition of increments of calcium chloride during the manufacture of a mitsumametype dessert showed that the soluble oxalate content of the ingredients could be efficiently converted to insoluble oxalates (Faudon \& Savage, 2014). The authors concluded that the addition of calcium salts to foods was an efficient way to reduce the potential absorption of soluble oxalates from processed foods. The possibility of using other commonly used calcium salts during processing and manufacturing of food and green juices has not been investigated.

The objective of this study was to investigate the effect of adding increments of four different calcium salts on the levels of soluble oxalate in fresh spinach juice.

\section{Materials and methods}

\subsection{Source of materials and preparation}

Fresh spinach (Spinacia oleracea L.) was purchased the New World Supermarket, Lincoln, Canterbury, in September 2015. Soil, dead leaves and stalk ends were removed using a stainless steel knife and the remaining portions were chopped into $10 \mathrm{~mm}$ pieces and processed using a blender (NutriBullet, NBR-1207M, $600 \mathrm{~W}$, Homeland Housewares LLC, Los Angeles, CA, USA) for $1.5 \mathrm{~min}$ at room temperature. All calcium additives were done in triplicate at the following rates: $0,50,100,200,300,400$ and $500 \mathrm{mg} / 100 \mathrm{~g}$ of homogenised spinach along with $100 \mathrm{~mL}$ of high purity water (Barnstead International, Dubuque, Iowa, USA, $18.0 \mathrm{M} \Omega \cdot \mathrm{cm}$ ). Four different experiments were carried out using additions of calcium chloride, calcium sulphate, calcium citrate and calcium carbonate (Table 1 ). Each conical flask was then placed in a shaking water bath at $25^{\circ} \mathrm{C}$ for $30 \mathrm{~min}$.

\subsection{Total and soluble oxalic acid determinations}

Triplicate $10 \mathrm{~g}$ samples of homogenised spinach were weighed into $250 \mathrm{ml}$ conical flasks and either extracted with $40 \mathrm{~mL}$ of $0.2 \mathrm{M} \mathrm{HCl}$ (Aristar, BDH Chemicals, Ltd., Poole, Dorset, UK) for total oxalate extraction or $40 \mathrm{~mL}$ of high purity water to extract soluble oxalates (Savage et al., 2000). Each extracted samples were then analysed by HPLC chromatography using the method outlined by Vanhanen and Savage (2015).

\subsection{Dry matter and $\mathrm{pH}$}

The dry matter (DM) contents of each homogenate mix were determined by drying in an oven (Watvic, Watson Victor Ltd., New Zealand) to a constant weight at $105^{\circ} \mathrm{C}$, following a method outlined by Ruiz (2001). pH values of the homogenised spinach samples were measured using a $\mathrm{pH}$ meter (Mettler Toledo, Schwerzenbach, Switzerland) with the accuracy of \pm 0.01 .

\subsection{Statistical analysis}

All calculations were performed using Excel 2010 (Microsoft for Windows). All analyses were carried out in triplicate and the results presented as means \pm standard error (SE). Statistical analysis was carried out using GenStat, Release 15.1 for Windows 7 (VSN International Ltd., Hemel Hempstead, Hertfordshire, UK) to determine the accumulated analysis of variance.

\section{Results}

The mean dry matter of the homogenised spinach was $8.62 \pm 0.37 \mathrm{~g} / 100 \mathrm{~g}$ FW and the mean total, soluble and insoluble oxalate contents of the untreated homogenised samples of spinach were $943.7 \pm 15.6,648.2 \pm 19.3$ and $295.5 \pm 29.4 \mathrm{mg} / 100 \mathrm{~g} \mathrm{FW}$, respectively. Soluble oxalate made up $68.7 \%$ of the total oxalate content.

Table 2 shows the \% reduction of soluble oxalate content of the homogenised spinach juice for each incremental addition of calcium carbonate, calcium chloride, calcium citrate and calcium sulphate. The data for the \% reduction of soluble oxalate in each of the prepared mixes are shown in Fig. 1. Table 2 also shows the $\mathrm{pH}$ of the initial homogenised samples (mean $6.27 \pm 0.01$ ) and the values following each incremental addition of the calcium salts. Significant $(\mathrm{p}<0.001)$ changes in the $\mathrm{pH}$ values from the initial homogenate to the addition of $500 \mathrm{mg}$ of calcium salt addition was observed for all salts except for calcium citrate. Significant $(p<0.001)$ changes in the remaining soluble oxalate contents when $500 \mathrm{mg}$ of calcium salt additions were made compared to the amounts observed in the initial homogenates.

\section{Discussion}

In this study, the homogenised spinach used contained a mean of $944 \mathrm{mg} / 100 \mathrm{~g}$ FW total oxalate, $648 \mathrm{mg} / 100 \mathrm{~g}$ FW of soluble oxalate and $295 \mathrm{mg} / 100 \mathrm{~g}$ FW of insoluble oxalate; these are within the range summarised earlier. The wide range of reported values for spinach has been noted previously (Noonan \& Savage, 1999). Some of the major factors that can impact on the variation in the oxalate content will be the age of the plant, growth conditions and climate (Noonan \& Savage, 1999).

With each calcium increment the total oxalate content remained unchanged (overall mean $941.7 \pm 20.2 \mathrm{mg} / 100 \mathrm{~g}$ FW) while the insoluble oxalate increased as the added calcium bonded with the soluble oxalates. The effectiveness of the addition of small amounts of calcium ions into the homogenised spinach juice can 
Table 1

Calcium additive used.

\begin{tabular}{|c|c|c|c|c|}
\hline Calcium additive & Manufacturer & $\mathrm{NZ} \$ / \mathrm{kg}$ & $\%$ Calcium $^{1}$ & Solubility in water at $25^{\circ} \mathrm{C}(\mathrm{g} / 100 \mathrm{~g})^{2}$ \\
\hline $\begin{array}{l}\text { Calcium carbonate } \\
\text { (E170) }\end{array}$ & Omya Australia Pty., Ltd. Sydney, Australia & 5.1 & $29.34 \pm 2.46$ & 0.00066 \\
\hline $\begin{array}{l}\text { Calcium chloride dehydrate } \\
\text { (E509) }\end{array}$ & Kirsch Pharma GmbH., Salzgitter, Germany & 35.0 & $25.60 \pm 3.17$ & 81.3 \\
\hline $\begin{array}{l}\text { Calcium citrate tetrahydrate } \\
\text { (E333) }\end{array}$ & Jost Chemical Co. St Louis, MO, USA & 45.0 & $24.71 \pm 2.04$ & 0.096 \\
\hline $\begin{array}{l}\text { Calcium sulphate dehydrate } \\
\quad \text { (E516) }\end{array}$ & Kirsch Pharma GmbH., Salzgitter, Germany & 28.0 & $33.71 \pm 9.69$ & 0.205 \\
\hline
\end{tabular}

1 Calcium content determined by IPC analysis.

2 Haynes and Lide (2010).

Table 2

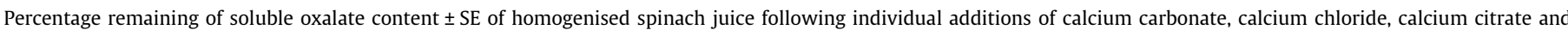
calcium sulphate and $\mathrm{pH} \pm \mathrm{SE}$.

\begin{tabular}{|c|c|c|c|c|c|c|c|c|}
\hline \multirow{2}{*}{$\begin{array}{l}\text { Calcium salt addition } \\
\text { ( } \mathrm{mg} / 100 \mathrm{~g} \text { spinach } \\
\text { homogenate) }\end{array}$} & \multicolumn{2}{|l|}{ Calcium carbonate } & \multicolumn{2}{|l|}{ Calcium chloride } & \multicolumn{2}{|l|}{ Calcium citrate } & \multicolumn{2}{|l|}{ Calcium sulphate } \\
\hline & $\begin{array}{l}\text { Remaining soluble } \\
\text { oxalate (\%) }\end{array}$ & $\mathrm{pH}$ & $\begin{array}{l}\text { Remaining soluble } \\
\text { oxalate (\%) }\end{array}$ & $\mathrm{pH}$ & $\begin{array}{l}\text { Remaining soluble } \\
\text { oxalate f }(\%)\end{array}$ & $\mathrm{pH}$ & $\begin{array}{l}\text { Remaining soluble } \\
\text { oxalate (\%) }\end{array}$ & $\mathrm{pH}$ \\
\hline 0 & 100 & $6.27 \pm 0.01$ & 100 & $6.27 \pm 0.01$ & 100 & $6.27 \pm 0.01$ & 100 & $6.27 \pm 0.01$ \\
\hline 50 & $90.16 \pm 3.18$ & $7.28 \pm 0.01$ & $67.98 \pm 1.16$ & $6.13 \pm 0.01$ & $79.24 \pm 0.44$ & $6.30 \pm 0.01$ & $74.45 \pm 0.50$ & $6.20 \pm 0.01$ \\
\hline 100 & $76.98 \pm 0.55$ & $7.74 \pm 0.01$ & $43.84 \pm 1.18$ & $6.09 \pm 0.01$ & $59.16 \pm 0.65$ & $6.38 \pm 0.01$ & $55.34 \pm 0.34$ & $6.20 \pm 0.01$ \\
\hline 200 & $64.79 \pm 0.68$ & $8.03 \pm 0.01$ & $12.92 \pm 0.41$ & $5.92 \pm 0.01$ & $27.29 \pm 4.58$ & $6.49 \pm 0.01$ & $17.64 \pm 0.62$ & $6.20 \pm 0.01$ \\
\hline 300 & $56.89 \pm 2.20$ & $8.13 \pm 0.01$ & $4.28 \pm 0.08$ & $5.77 \pm 0.01$ & $20.52 \pm 1.31$ & $6.52 \pm 0.01$ & $8.13 \pm 0.34$ & $6.16 \pm 0.01$ \\
\hline 400 & $52.73 \pm 0.37$ & $8.16 \pm 0.01$ & $2.51 \pm 0.06$ & $5.68 \pm 0.01$ & $13.47 \pm 0.42$ & $6.49 \pm 0.01$ & $5.55 \pm 0.34$ & $6.10 \pm 0.01$ \\
\hline 500 & $50.69 \pm 0.31$ & $8.26 \pm 0.01$ & $1.75 \pm 0.06$ & $5.62 \pm 0.01$ & $10.46 \pm 0.85$ & $6.44 \pm 0.01$ & $4.72 \pm 0.11$ & $6.06 \pm 0.01$ \\
\hline \multicolumn{2}{|l|}{ Analysis of variance } & \multicolumn{2}{|l|}{ d.f. } & \multicolumn{3}{|c|}{ Remaining soluble oxalate (\%) } & \multicolumn{2}{|l|}{$\mathrm{pH}$} \\
\hline \multicolumn{2}{|l|}{ Type of calcium salt } & \multicolumn{2}{|l|}{3} & \multicolumn{3}{|l|}{$* * *$} & \multicolumn{2}{|l|}{$* * *$} \\
\hline \multicolumn{2}{|c|}{ Concentration of calcium salt } & \multicolumn{2}{|l|}{6} & \multicolumn{3}{|l|}{$* * *$} & \multicolumn{2}{|l|}{$* * *$} \\
\hline \multicolumn{2}{|c|}{ Type $\times$ Concentration of calcium salt } & \multicolumn{2}{|l|}{18} & \multicolumn{3}{|l|}{$* * *$} & \multicolumn{2}{|l|}{$* * *$} \\
\hline \multicolumn{2}{|l|}{ LSD } & \multicolumn{2}{|l|}{-} & \multicolumn{3}{|l|}{3.546} & \multicolumn{2}{|l|}{0.016} \\
\hline
\end{tabular}

Significance: ${ }^{* * *} \mathrm{p}<0.001,{ }^{* *} \mathrm{p}<0.01,{ }^{*} \mathrm{p}<0.05$, NS = not significant $(\mathrm{p}>0.05)$; LSD least significant difference.

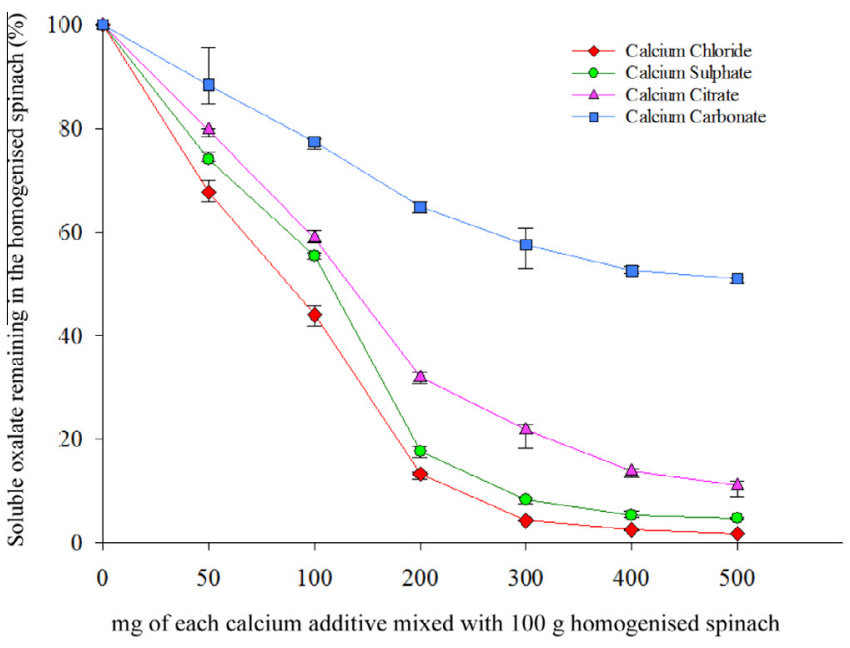

Fig. 1. Effect of adding four different calcium ions on the percentage of soluble oxalate remaining in $100 \mathrm{~g}$ of homogenised spinach juice (error bars indicate standard error of the mean)

be seen in Fig. 1. Each calcium was added to the spinach homogenate by weight and it should be noted that the calcium content of each salt varied from 24.7 to $33.7 \%$ of the solid (Table 1). Calcium chloride was the most effective additive to reduce the soluble oxalate content of the mixes as the addition of $500 \mathrm{mg}$ to $100 \mathrm{~g}$ of spinach mixture, reduced the soluble oxalate content by $98.3 \%$. In contrast, the addition of $500 \mathrm{mg}$ of calcium carbonate only reduced the soluble oxalate content by $49.3 \%$. There appeared to be no rela- tionship between the calcium content of the four salts investigated and their potential to reduce the soluble oxalate content of the spinach mixture.

It was interesting to note that the $\mathrm{pH}$ change in the incremental mixtures was a good indicator of the effective reduction of soluble oxalate in each of the incremental mixes. Addition of $500 \mathrm{mg}$ calcium chloride to $100 \mathrm{~g}$ of the spinach mixture, reduced the $\mathrm{pH}$ value to $5.62 \pm 0.01$ while the addition of $500 \mathrm{mg}$ of calcium carbonate was the least effective at reducing the soluble oxalate content and also increased the mix to $\mathrm{pH}$ 8.26. The effectiveness of calcium carbonate may be reduced by the fact that calcium carbonate is the least soluble calcium salt investigated (Table 1) but the addition of this calcium salt to the spinach mixture had a significant effect on the $\mathrm{pH}$ of the mixture.

The speciation diagram published by Simpson et al. (2009) shows that in an ideal pure water solution $\mathrm{pH}$ influences the occurrence of the three possible forms of oxalate species. The $\mathrm{pH}$ of the original spinach homogenate was 6.7 , which, in an ideal solution, would suggest that most of the oxalate would be $\left(\mathrm{C}_{2} \mathrm{O}_{4}\right)^{2-}$ and would readily combine with soluble calcium in the spinach mixture to form insoluble oxalate. Addition of $500 \mathrm{mg}$ calcium carbonate/100 $\mathrm{g}$ homogenised spinach changed the $\mathrm{pH}$ of the mixture to 8.26 which in theory should increase the amount of $\left(\mathrm{C}_{2} \mathrm{O}_{4}\right)^{2-}$ available to bind to soluble calcium in the mixture. However, this did not occur. It is possible that not all of the calcium was fully soluble in the spinach mixture (Table 1). Addition of calcium chloride, calcium sulphate and calcium citrate were effective at reducing the soluble oxalate content of the spinach mixture when $500 \mathrm{mg}$ was added to $100 \mathrm{~g}$ homogenised spinach. This was achieved with only a small change in the overall pH (mean $6.04 \pm 0.24$ ). In practice, calcium chloride was the most effective calcium salt to bind to 
the soluble oxalate. These results strongly suggest that the homogenised mixture of spinach did not respond in the same way as an ideal solution would behave in pure water. This suggests that a more complex interaction may be taking place between the added calcium, soluble oxalate and other constituents in the spinach leaf matrix, such as other minerals or complex carbohydrates, when the $\mathrm{pH}$ was altered.

This study confirms that the addition of modest amounts of calcium chloride to a spinach homogenate would be the most effective additive even though it was more expensive than the cheapest calcium additive, calcium carbonate, which was very ineffective at reducing the soluble oxalate content in the spinach mix. Calcium carbonate also has the unfortunate effect of making the juice more alkaline and this would have implications for the storage of the juice and may have an effect on the taste of the juice.

Overall, this study showed that a $50 \%$ reduction in the soluble oxalate content of a spinach homogenate could be achieved by the addition of $88 \mathrm{mg}$ of calcium chloride to $100 \mathrm{~g}$ of spinach homogenate. This would have a significant effect on the soluble oxalate intake of a regular consumer of green juices containing spinach. In contrast, calcium sulphate calcium chloride and calcium carbonate could achieve a 50\% reduction in soluble oxalate content by the addition of 113,125 and $500 \mathrm{mg} / 100 \mathrm{~g}$ FW, respectively.

\section{Conclusions}

Spinach leaves and stems are often homogenised and then used as the base vegetable to make green juices. As green juices are not cooked or processed to allow removal or reduction the soluble oxalate content this poses a risk to the consumer. However, the addition of calcium ions during processing at room temperature offers the opportunity to convert some of the soluble oxalates in the juices into insoluble oxalates that are less likely to be absorbed from the digestive tract. This research has highlighted the positive effect of the addition of four different calcium sources during the preparation of the homogenised spinach mixture. Calcium chloride was the most effective additive, while calcium carbonate was the least effective additive in reducing the soluble oxalate contents in the green juice. Overall, the addition of even small amounts of soluble calcium would make the green juice considerably safer to consume by reducing the soluble oxalate content.

\section{Acknowledgements}

This study was funded by Lincoln University, Canterbury, New Zealand. The authors wish to thank Diana Sari Kusuma, for her help throughout the experiment. The authors would also wish to thank Wendy Y. Y. Liu and Dean M. O'Connell for their guidance and suggestions on statistical data analysis throughout this study.

\section{References}

Akhtar, M. S., Israr, B., Bhatty, N., \& Ali, A. (2011). Effect of cooking on soluble and insoluble oxalate contents in selected Pakistani vegetables and beans. International Journal of Food Properties, 14(1), 241-249.
Brogren, M., \& Savage, G. P. (2003). Bioavailability of soluble oxalate from spinach eaten with and without milk products. Asia Pacific Journal of Clinical Nutrition, 12 (2), 219-224.

Fang, H. C., Lee, P. T., Lu, P. J., Chen, C. L., Chang, T. Y., Hsu, C. Y., \& Chou, K. J. (2008), Mechanisms of star fruit-induced acute renal failure. Food and Chemical Toxicology, 46(5), 1744-1752.

Faudon, S., \& Savage, G. (2014). Manufacture of a low oxalate mitsumame-type dessert using rhubarb juice and calcium salts. Journal of Food and Nutrition Sciences, 5, 1621-1627.

Getting, J. E., Gregoire, J. R., Phul, A., \& Kasten, M. J. (2013). Oxalate nephropathy due to 'Juicing': Case report and review. The American Journal of Medicine, 126(9), $768-772$.

Ghosh Das, S., \& Savage, G. P. (2013). Oxalate content of Indian spinach dishes cooked in a wok. Journal of Food Composition and Analysis, 30(2), 125-129.

Haynes, W. M., \& Lide, D. R. (Eds.). (2010). CRC handbook of chemistry and physics: A ready-reference book of chemical and physical data (91st ed.. Boca Raton, USA: CRC Press.

Liebman, M., \& Costa, G. (2000). Effects of calcium and magnesium on urinary oxalate excretion after oxalate loads. Journal of Urology, 163, 1565-1569.

Liu, X. X., Zhou, K., Hu, Y., Jin, R., Lu, L. L., Jin, C. W., \& Lin, X. Y. (2015). Oxalate synthesis in leaves is associated with root uptake of nitrate and its assimilation in spinach (Spinacia oleracea L.) plants. Journal of the Science of Food and Agriculture, 95(10), 2105-2116.

Massey, L. K. (2003). Dietary influences on urinary oxalate and risk of kidney stones. Frontiers in Bioscience, 8, s584-s594.

Msagati, T. A. M. (2012). Chemistry of Food Additives and Preservatives. Somerset, NJ, USA: John Wiley \& Sons. Available from <http://site.ebrary.com/lib/ lincoln/docDetail.action?docID=10653552> Retrieved 12.11.15.

Noonan, S. C., \& Savage, G. P. (1999). Oxalate content of foods and its effect on humans. Asia Pacific Journal of Clinical Nutrition, 8(1), 64-74.

Ogawa, Y., Miyazato, T., \& Hatano, T. (2000). Oxalate and urinary stones. World Journal of Surgery, 24, 1154-1159.

Oscarsson, K. V., \& Savage, G. P. (2007). Composition and availability of soluble and insoluble oxalates in raw and cooked taro (Colocasia esculenta var. Schott) leaves. Food Chemistry, 101(2), 559-562.

Ruiz, R. P. (2001). Gravimetric determination of water by drying and weighing. In V. Chandra (Ed.), Current protocols in food analytical chemistry. http://dx.doi.org/ 10.1002/0471142913.faa0101s00. A1.1.1-A1.1..

Saltmarsh, M. (Ed.). (2013). Essential Guide to Food Additives (4th ed.). Cambridge, GBR: Royal Society of Chemistry. Available from <http://site.ebrary.com/lib/ lincoln/docDetail.action?docID=10671441> Retrieved 12.11.15.

Savage, G. P., Charrier, M. J. S., \& Vanhanen, L. (2003). Bioavailability of soluble oxalate from tea and the effect of consuming milk with the tea. European Journal of Clinical Nutrition, 57(3), 415-419.

Savage, G. P., Martensson, L., \& Sedcole, J. R. (2009). Composition of oxalates in baked taro (Colocasia esculenta var. Schott) leaves cooked alone or with additions of cows milk or coconut milk. Journal of Food Composition and Analysis, 22(1), 83-86.

Savage, G. P., Vanhanen, L., Mason, S. M., \& Ross, A. B. (2000). Effect of cooking on the soluble and insoluble oxalate content of some New Zealand foods. Journal of Food Composition and Analysis, 13(3), 201-206.

Simpson, T. S., Savage, G. P., Sherlock, R., \& Vanhanen, L. P. (2009). Oxalate content of silver beet leaves (Beta vulgaris var. cicla) at different stages of maturation and the effect of cooking with different milk sources. Journal of Agricultural and Food Chemistry, 57(22), 10804-10808.

Vanhanen, L., \& Savage, G. (2015). Comparison of oxalate contents and recovery from two green juices prepared using a masticating juicer or a high speed blender. NFS Journal, 1, 20-23.

Walker, N. W. (1951). Your fountain of health: Fresh fruit and vegetable juices. Wickenburg, Ariz., USA: Norwalk Press.

Wang, D. (2012). Food Science and Technology: Food Chemistry. Hauppauge, NY, USA: Nova. Available from <http://site.ebrary.com/lib/lincoln/docDetail. action?docID=10654638> Retrieved 14.11.15.

Wang, Y. C., Bleich, S. N., \& Gortmaker, S. L. (2008). Increasing caloric contribution from sugar-sweetened beverages and 100\% fruit juices among US children and adolescents, 1988-2004. Paediatrics, 121(6), e1604. 